\title{
CD8B wt Allele
}

National Cancer Institute

\section{Source}

National Cancer Institute. CD8B wt Allele. NCI Thesaurus. Code C51135.

Human CD8B wild-type allele is located within 2p12 and is approximately $47 \mathrm{~kb}$ in length.

This allele, which encodes T-cell surface glycoprotein CD8 beta chain protein, is involved

in the efficient mediation of cell-cell interactions within the immune system. 